\title{
第6回「東アジアと同時代日本語文学フォーラム」 2018上海大会印象記
}

高 潔

هkoketsu2001@hotmail.com

2018年10月20日から 21日までの二日間、復旦大学で、〈「レンタル」と近現代東アジア文化〉 をテーマとするシンポジウムを聴講させていただきました。発表者は中国、日本、韓国、台湾 地域から来た学者や院生だけでなく、インドネシア、ベトナム、タイからの学者も一堂に集 い国際色豊かな大会という印象が強く残されました。

「レンタル」と言うと、中国語では「借贷」という言葉に当りますが、酒井直樹先生は基調講演 「アジアという借りてきた指標：文明的転移と植民地的近代ににおいて、「アジア」という私たち が当たり前のように使っている地理概念を、「借りてきた」ものと新たな照射を当て、アジアが あくまでも西洋人にとっての地理的指標、西洋のアイデンティティを保障する概念で、裏には 常に西洋が潜んでいると指摘しています。考えてみ机ば、近代以降、自然科学に限らず、人文 社会学のすべての分野にわたり、西洋の概念、原理、研究方法を使わないところはないと言っ ていいほど、世界は西洋一色の道をグローバル化に向けて急進しているのです。啓蒙思想家の 福沢諭吉は「脱亜入欧」を揭げていますが、その離脱しようとするアジアでさえ、欧米から教 わったものであります。近代に入ってから、われわれ「アジア」の人びとは専ら「レンタル」を して、今日まで発展してきたような気がしました。

メイン会場の四つの講演はまた、いずれも「租借」「租借地」租界」をめぐって議論を展開され たのです。ここでは、「レンタル」の度には差がありますが、朝鮮半島と台湾は完全に植民地に なり、日本帝国の領土の一部分になっています。上海は著名な租界都市で、英・仏・米など各国 の租界が軒を並べて、また虹口のような日本人居留民が集中して住んでいた界隈もあります。 大連という都市はロシアと日本が活躍していた都市で、20世紀以降、主に日本人のモダニズム の楽園になっています。私たちは日常生活で人に何かを借りるとき、その人の意向を伺い、承 諾をもらわなければなりません。もしその人を妿かしてなにかを強制的に取り上げるなら、そ れは「奪う」ことで、「強盗」といら違法行為になります。帝国時代の「租借」は一応、当事者全員 が契約にサインし、合法的な手続きを取っていますが、「租借」される側がほとんどやむを得ず 貸し出したので、「レンタル」という八イカラな外来語でまとめるには、どうもなにか、泥臭 いものが隠蔽されているような気がしてなりません。でも、考えてみれば、これほど多くの 学者が真剣にその隠蔽された歴史の全貌を明らかにしようと努力していること自身、それも当 時の関係国の学者が共同で歴史の傷を抉り出し、再発予防のために完全な治癒を目指すこと、

これはまたどれだけ偉大なことなのか、感慨無量になりました。

日本語を専攻とし、日本文化と中国文化の狭間に生きている私にとって、各分会場の発表は 
どれもこれも興味をそそられる研究ですが、やたらに会場を変えるのを遠慮して、まじめに二 つの分会場の発表を最後まで聞きました。「1930年前後のアジア女性雑誌」会場では、女性の創 作者、女性向けの出版物に着目して、20世紀30年代の女性の創作者と読者と海外とのつながり を浮き彫りにしました。時代の先端を行く女性たちに感心しましたが、その雑誌の名前がなぜ 「女人」という仏教っぽい言葉を使うのか、ちょっと気になりました。

「租界地・上海」分会場では、穆時英が「街の風景」を創作するとき、実は池谷信三郎の「橋」の 冒頭部分を借用したことを面白く聞かせてもらいました。近代以降のテンポの速い社会におい て、文学の創作も高速化の時代の雰囲気の中で、借用でまかなうことが増えたという結論もま た、あわただしい毎日を送っているわたしたちにとって、納得のいく結論といわなければな りません。日本近代文学の中で、森鴎外の「寒山拾得」、芥川龍之介の「酒虫」黄梁夢」、太宰治の 「竹青」など、中国の古典を借用する作品がよく知られていますが、20世紀前半期の中国の作家 たちも同時代の日本の作家の作品をうまく自分の作品に取り入れていることは、当時の中日両 国の文学関係の緊密性を改めて感じさせられました。今まで、文学史に取り残されてきた歴史 の一断面をちらりと見たような気がしました。

最近、各シンポジウムで発表する大学院生の姿をよく見かけることがあります。中国語で はよく「研究生专场」といういかにも殺風景で事務的な分会場の名前を使いますが、この大会で は「次世代フォーラム」といらいかにも、明るい未来が感じられる名称を使っています。確かに 研究の情熱に燃えている大学院生たちに未来がかかっています。戦後七十年以上も過ぎた今、 元気溌溂とした大学院生は歴史の傷を引きずらず、また従来の見方にとらわれずに、百年近い 前の「レンタル」に満ちた時代の歴史を掘り起こし、その全貌を明らかにすることを期待してや みません。

この国際色豊かな大会を足場に、参加した研究者全員は、ナショナリズムではなくグローバ リズムの視点で、国境を越えた文学、文化の足取りをしっかり見つめて、次世代にバトンタッ チしていくことを固く信じております。

\section{高潔 Jie Gao}

(中国) 上海外国語大学日本文化経済学院教授。日本文学研究、中日比較文学研究。主著に「谷崎润一郎文学 的“非东方主义”解读——以苏州纪行》《秦淮之夜》《西湖之月》为中心」(『日语学习与研究』第 4 期. 2018)、『佐藤春夫〈女诚扇绮谈〉的台湾叙事』(外国文学评论」第1期, 2013)など。 